\title{
Parasitic Gastro-Enteritis (PGE) Concurrent with Eperythrozoonosis in a Goat: A Case Report
}

\author{
${ }^{1,3}$ Faez Firdaus Jesse Abdullah, ${ }^{1,5}$ Lawan Adamu, ${ }^{1}$ Mohd Hero Azuan B. \\ Jamal, ${ }^{1}$ Abdinasir Yusuf Osman, ${ }^{1,3}$, Abdul Wahid Haron, ${ }^{4}$ Dayang Norhaizam \\ Awang and ${ }^{4}$ Noorashimah Roslim \\ ${ }^{1}$ Department of Veterinary Clinical Studies, Faculty of Veterinary Medicine, Universiti Putra Malaysia, 43400 \\ Serdang, Selangor, Malaysia, \\ ${ }^{3}$ Research Centre for Ruminant Disease, Universiti Putra Malaysia, 43400 Serdang, Selangor, Malaysia, \\ ${ }^{4}$ University Veterinary Hospital, Universiti Putra Malaysia, 43400 Serdang, Selangor, Malaysia, \\ ${ }^{5}$ Department of Veterinary Medicine, Faculty of Veterinary Medicine, University of Maiduguri, PMB1069, \\ Borno State, Nigeria
}

\begin{abstract}
A 7 month-old, male Katjang cross goat weighing 35kg with body condition score of 3/5 was presented to Large Animal Ward, University Veterinary Hospital (UVH). The goat had pale mucous membrane and diarrhoea. The goat had moderate normocytic, normochromic anaemia with packed cell volume (PCV) of $0.14(0.22-0.32)$ and low normal plasma protein, neutrophilia with left shift and monocytosis, including hyponatraemia, hypocalcaemia and hypoalbuminaemia with increased muscle enzyme $(C K)$. Thin blood film stained with Geimsa showed evidence of blood parasites and mycoplasma sp. $0.1 \%$ of RBC was infected and with high strongyle infestation (13900 epg) using modified McMaster technique. Blood transfusion was done as a result of decreased PCV value to 0.13 on the second day of hospitalization. Parasitic gastro-enteritis (PGE) concurrent with eperythrozoonosis infection was diagnosed in the goat.
\end{abstract}

Keywords: Parasitic gastro-enteritis, eperythrozoonosis, anaemia, blood transfusion, PCV

\section{Introduction}

Parasitic Gastro enteritis or PGE is a disease complex associated with number of nematode species mostly strongyle comprising of Heamonchus, Trichostrongylus, Oesophagostomum, Cooperia, Strongyloides and cestode most commonly Monesia species. Weight loss, poor performance and diarrhea are the main presenting signs of PGE. Anaemia and weight loss usually with no change in feacal consistency are characteristic signs of haemonchosis.

Eperythrocytic parasites previously known as Eperythrozoon and Haemobartonella have been reclassified to the genus Mycoplasma [1]. Mycoplasma ovis is an uncultivated, wall-less bacterium that parasitizes the surface of goat or sheep erythrocytes. This organism is transmitted by blood-feeding arthropods and parasitizes in goat and sheep-rearing regions throughout the world. Signs of infection include mild to severe haemolytic anaemia, as well as icterus; animals may exhibit poor weight gain and depression, but death is rare in adults. Infections are frequently imperceptible and chronic.

Anaemia is suggested clinically by pale or white mucous membrane, exercise intolerance, tachypnea, tachycardia, possible systolic murmur and also leading to lethargic state in affected animal. Anaemia is a common and important clinical presentation in goats.

Patient signalment

\section{Case Report}

A 7 month-old, Katjang cross male goat weighing $35 \mathrm{~kg}$ with body condition score of 3 out of 5 . The vaccination and deworming status was up to date. The goat was managed intensively. The goat had been in recumbency for 1 week, blood sample was collected and the PCV result was 15\% on 5th of December 2012. The goat was presented to large animal ward of UVH on the $12^{\text {th }}$ of December 2012 with primary complaint of pale mucous membrane and pasty faeces.

\section{Physical examination}

On physical examination, the goat was presented with body temperature of $39.5{ }^{\circ} \mathrm{C}$, heart rate of 160 bpm and respiratory rate of 36 circles per minute. The capillary refill time was more than 2 seconds and skin tent of 4 seconds; the mucous membrane was pale with 5\% dehydration. Pasty faeces and nasal discharge were also observed. 


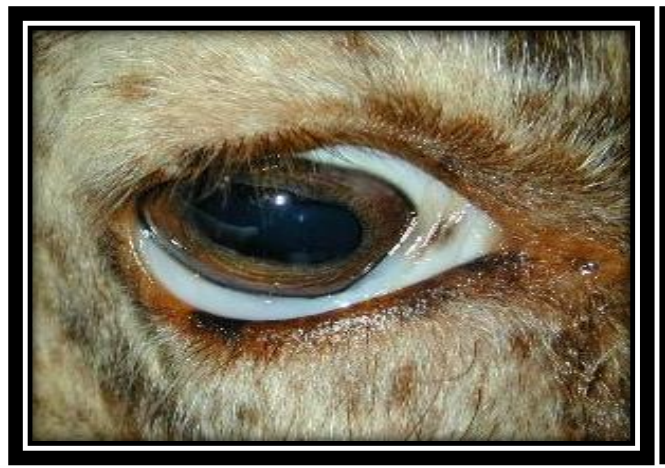

Figure 1: Pale mucous membrane

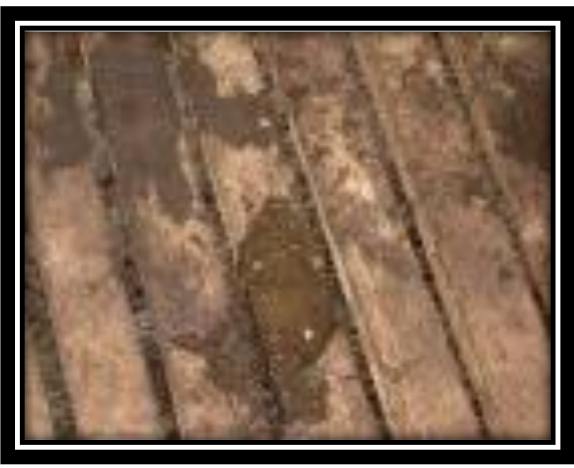

Figure 2: Pasty faeces

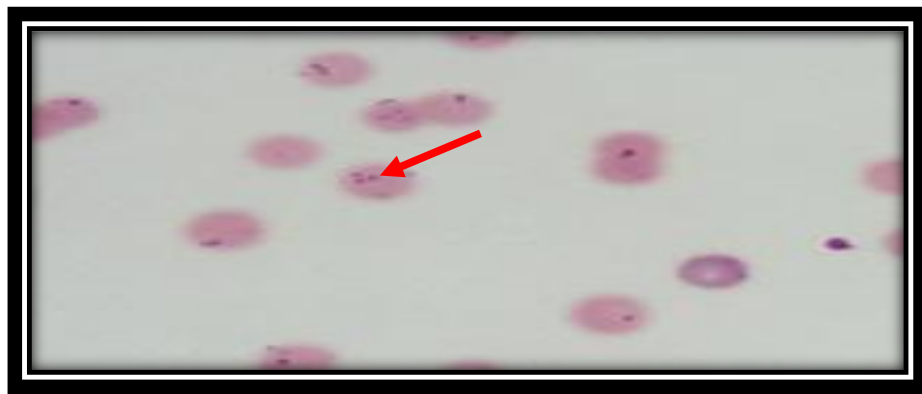

Figure 3: Geimsa-stained blood smear showing eperythrocytic bacteria typical of Mycoplasma ovis

\section{Differential diagnosis}

The problem lists were pale mucous membrane and pasty faeces (diarrhoea) and the differential diagnosis were PGE, anaplasmosis, Mycoplasmosis (Eperythrozoonosis) and coccidiosis.

\section{Diagnostic work up}

The preliminary diagnostic work up performed was the complete blood count (CBC) and serum biochemistry, blood and faecal sample were sent to parasitology laboratory. The result of $\mathrm{CBC}$ showed moderate normocytic, normochromic anaemia with packed cell volume (PCV) of 0.14 (0.22-0.32) and the low normal plasma protein may be due to haemorrhagic anaemia. The neutrophilia with left shift and monocytosis was suggestive of infection or inflammation. The serum and biochemistry revealed hyponatraemia and hypocalcaemia; these could be due to dehydration and inappetance. The slight increase in muscle enzyme indicates muscle injury and it could be associated to the recumbency period of up one week and hypoalbuminaemia could be due to malnutrition or protein lost enteropathy. There was an evidence of blood parasite of Mycoplasma species indicated by the thin blood film stained with Geimsa where $0.1 \%$ of the RBC was infected and the high (13900 epg) strongyle infestation (> 1500 epg) was obvious using modified McMaster technique. This result was consistent with the clinical signs.

\section{Final diagnosis}

From the diagnostic work up results, the goat was diagnosed as having parasitic gastro-enteritis (PGE) concurrent with eperythrozoonosis.

Table 1: Haematology, biochemistry and interpretation of results

\begin{tabular}{|c|c|c|c|c|c|c|c|}
\hline Haemogram & $\begin{array}{l}6 / 1 \\
2 \\
\end{array}$ & Ref. & $\begin{array}{l}\text { Interpretatio } \\
\mathrm{n}\end{array}$ & Biochemistry & $6 / 12$ & Ref. & Interpretation \\
\hline $\begin{array}{l}\text { Erythrocytes } \\
\text { (RBC) }\end{array}$ & $\begin{array}{l}7.1 \\
2\end{array}$ & $8-18$ & $\begin{array}{l}\text { Normocytic } \\
\text { normochrom }\end{array}$ & Sodium & 140.2 & $\begin{array}{l}142- \\
155\end{array}$ & Hyponatraemia \\
\hline Haemoglobin & $\begin{array}{l}40 . \\
2\end{array}$ & $80-120$ & ic anaemia & Potassium & 4.4 & $3.5-6.7$ & \\
\hline PCV & $\begin{array}{l}0.1 \\
4\end{array}$ & $\begin{array}{l}0.22- \\
0.38\end{array}$ & & Chloride & 106.2 & $99-110$ & \\
\hline MCV & 20 & $16-25$ & & Calcium & 1.72 & $2.2-3.2$ & Hypocalcaemia \\
\hline $\mathrm{MCHC}$ & $\begin{array}{l}28 \\
7\end{array}$ & $300-360$ & & $\begin{array}{l}\text { Inorganic } \\
\text { phosphate }\end{array}$ & 1.74 & $1.6-2.3$ & \\
\hline $\begin{array}{l}\text { Leukocytes } \\
\text { (WBC) }\end{array}$ & $\begin{array}{l}17 . \\
9\end{array}$ & $4-13$ & & Urea & 4.4 & $3.5-7.1$ & \\
\hline Band neutrophils & $\begin{array}{l}0.1 \\
8\end{array}$ & 0 & $\begin{array}{l}\text { Neutrophilia } \\
\text { with left }\end{array}$ & Creatinine & 64 & $88-160$ & \\
\hline Seg. Neutrophils & 9.4 & $1.2-7.2$ & shift & Glucose & & $2.7-4.2$ & \\
\hline
\end{tabular}




\begin{tabular}{|c|c|c|c|c|c|c|c|}
\hline & 9 & & & & & & \\
\hline Lymphocytes & $\begin{array}{l}7.1 \\
6\end{array}$ & $2.0-9.0$ & \multirow{9}{*}{ Monocytosis } & $\begin{array}{l}\text { Bilirubin, } \\
\text { Total }\end{array}$ & 0.4 & $1.7-6.8$ & \\
\hline Monocytes & $\begin{array}{l}0.7 \\
2\end{array}$ & $<0.55$ & & $\begin{array}{l}\text { Bilirubin, } \\
\text { Conjugated }\end{array}$ & $<0.1$ & $1.7-5.0$ & \\
\hline Eosinophils & $\begin{array}{l}0.1 \\
8\end{array}$ & $\begin{array}{l}0.05- \\
0.65\end{array}$ & & GGT & & $30-50$ & \multirow{4}{*}{ Muscle injury } \\
\hline Basophils & $\begin{array}{l}0.1 \\
8\end{array}$ & $<0.3$ & & AST & & $50-100$ & \\
\hline Thrombocytes & - & $250-750$ & & $\mathrm{CK}(\mathrm{CPK})$ & 320 & $\begin{array}{l}100- \\
200\end{array}$ & \\
\hline Plasma protein & 60 & $60-75$ & & $\mathrm{LDH}$ & 1355 & $\begin{array}{l}123- \\
392\end{array}$ & \\
\hline \multirow[t]{3}{*}{ Icterus index } & 2 & $<15$ & & $\begin{array}{l}\text { Total protein } \\
\text { (serum) }\end{array}$ & 58.8 & $55-70$ & \multirow{3}{*}{$\begin{array}{l}\text { Hypoalbuminaem } \\
\text { ia }\end{array}$} \\
\hline & & & & Albumin & 17.8 & $25-35$ & \\
\hline & & & & Globulin & 40.1 & $25-45$ & \\
\hline
\end{tabular}

III. Treatment

The goat was treated with Fercobsang at the dose rate of $1 \mathrm{ml} / 10 \mathrm{~kg}, 3.5 \mathrm{ml}$ was administered intramuscularly (IM) SID for 11 days as iron supplement. Blood transfusion was done on day 2 of hospitalization to improve the anaemic condition of the goat. Oxytetracyline was administered at the dose rate of $1 \mathrm{ml} / 10 \mathrm{~kg}, 3.5$ $\mathrm{ml}$ was administered IM as treatment option against Mycoplasma ovis. Ivermectin injection was administered at the dose rate of $1 \mathrm{ml} / 50 \mathrm{~kg}$, subcutaneously $(\mathrm{SC}$ ) against ectoparasites and endoparasites, $0.7 \mathrm{ml}$ was administered SC. Norodine 24 (Sulphadiazine trimenthoprim) $1 \mathrm{ml}$ was administered IM for 6 day as an option for the respiratory problem and Flunixin meglumine $2.2 \mathrm{mg} / \mathrm{kg} 0.8 \mathrm{ml}$ was administered IM as anti inflammation and anti pyrexic agents. To correct the $5 \%$ dehydration, sodium chloride $0.9 \%$ was administered subcutaneously.

\section{Progression}

The diarrhea was resolved on day 3 of hospitalization. The nasal discharges still persist but improved. On day 5 of hospitalization, the PVC increased from 0.13 to 0.16 (0.22-0.32). However, the PCV dropped to 0.15 on day 8 of hospitalization hence the second blood transfusion was done. The dehydration and inappetance were resolved on day 8 . This goat was send home on day 14 with PVC of 23\%, negative for the Mycoplasma ovis blood parasite and with significantly lower number of strongyle.

\section{Diagnosis of Eperythrozoonosis}

\section{Discussions}

The diagnosis of eperythrozoonosis has two methods, comprising of Geimsa blood stained smear and polymerase chain reaction (PCR). Even though PCR have high sensitivity and specificity [2] compare to Geimsa blood stained smear method [3], Geimsa stained blood smear method is still the preferred method when considering the cost benefit factors and for quick diagnostic purposes. Besides that, in the present case report due to high level of parasitaemia the organism was able to be detected in the erythrocytes. However, in case of low level of parasitaemia, repeated testing needs to be done [4].

\section{Diagnosis of Parasitic gastro-enteritis (PGE)}

This is based on history of grazing and clinical signs [5], supported by faecal egg count using modified McMaster technique and larval culture. A faecal egg count of 500-100 eggs per gram (epg) is considered indicative of subclinical PGE in lambs without overt signs of disease, and similar count may be appropriate to the diagnosis of PGE in kids [6]. In adult, egg counts in excess of 2000 epg are usually indicative of clinical disease. Counts of 500 to $2000 \mathrm{epg}$ are suggestive of subclinical parasitism [6].

\section{Consideration of Blood Transfusion in Goat}

Goats are considered domestic species with large spleen. Hence, in healthy goat the spleen can accommodate acute blood lost up to $25 \%$ or $50 \%$ of loss over 24 hours. In this case report, fluid replacement is of more concern than blood replacement. In chronic blood loss, such as parasitic disease, PCV may reach a level as low as $9 \%$ but without overt clinical manifestations of anaemia, stress or concurrent diseases, blood transfusion is not indicated here. But in this case report, blood transfusion is indicated because the goat was having parasitic disease concurrent with eperythrozoonosis and having stress due to malnutrition. 


\section{Prevention and control Mycoplasma ovis}

In order to prevent the Mycoplasma ovis, the transmission of the disease by biting insects such as flea and mosquito must be control. Besides that, the practice of good hygiene is paramount and this is achieved by keep the instruments clean from infected RBC between animals. Paying careful attention to nutrition, worm control, and trace element supplementation in order to limit the severity of the disease.

\section{Control and management of PGE}

PGE can be control by combining both chemical and good management. Strategic use of chemical or anthelmintic is designed to reduce worm burden and is highly effective against adults and immature stage. However, the use of recommended dose, and proper timing of administration are important to prevent anthelmintic resistance.

Lastly, the improvement of the nutrition status especially the protein level is imperative. This will help to reduce larval establishment by improving the immunity status. Besides nutrition, feeding management is also important. The time of cut and carry in any intensive farming need to be done when the sun has rises. This is to prevent the feeding of pasture that may contain free living L3.

\section{Acknowledgement}

The authors wish to acknowledge En Nazim Razali Kanini, En Mohd Jefri, University Veterinary Hospital (UVH), and Faculty of Veterinary Medicine Universiti Putra Malaysia for their technical assistance.

\section{References}

[1] Neimark, H., Hoff, B. and Ganter, M. 2004. Mycoplasma ovis comb. Nov. (formerly Eperythrozoon ovis), an epierythrocytic agent of haemolytic anaemia in sheep and goats. Int. J. Syst. Evol. Microbiol. 54: 365-371.

[2] Tagawa, M., Matsumoto, K. and Inokuma, H. 2008. Molecular detection of Mycoplasma wenyonii and 'Candidatus Mycoplasma haemobos' in cattle in Hokkaido, Japan. Vet. Microbiol. 132: 177-180.

[3] Hoelzle, L.E., Adelt, D., Hoelzle, K., Heinritzi, K., Wittenbrink, M.M., 2003. Development of a diagnostic PCR assay based on novel DNA sequences for the detection of Mycoplasma Suis (Eperythrozoon Suis) in porcine blood. Vet. Microbiol. 93, $185-196$.

[4] Brun-Hansen, H., Gronstol, H., Waldeland, H. \& Hoff, B. (1997). Eperythrozoon ovis infection in a commercial flock of sheep. Zentbl Veterinarmed B 44, 295-299.

[5] Eysker, M and Ploeger, H. W. (2000). Value of present diagnostic methods for gastrointestinal nematode infections in ruminants Parasitology, 120(07), 109-119.

[6] Smith, Mary C., David Sherman. (2009). Goat Medicine. 2th ed., Wiley-Blackwell., USA. 